\title{
Removal of Chloride in Bottom Ash from the Industrial and Municipal Solid Waste Incinerators
}

\author{
Ryoji ITO ${ }^{a *}$, Toyohisa FUJITA ${ }^{a}$, Jun SADAKI ${ }^{a}$, Yoichiro MATSUMOTO ${ }^{b}$ and Ji-Whan AHN ${ }^{c}$ \\ ${ }^{a}$ Dept. of Geosystem Eng., Graduate School of Eng., The University of Tokyo \\ 7-3-1 Hongo, Bunkyo-ku, Tokyo, 113-8656, Japan \\ ${ }^{b}$ Dept. of Mechanical Eng., Graduate School of Eng., The University of Tokyo, Japan \\ ${ }^{\circ}$ Korea Institute of Geoscience \& Mineral Resources, Korea \\ E-mail address :tt47357@mail.ecc.u-tokyo.ac.jp
}

\begin{abstract}
In the present work, recycling of bottom ash from both industrial waste and municipal solid waste incinerators (MSWI) was investigated. In order to recycle bottom ash as raw materials for cement production, it is necessary to remove chloride, which causes metal erosion in reinforced concrete. Therefore, experiments for removing chloride were carried out by washing bottom ash in order to obtain efficient washing conditions. The following conditions were investigated: $\mathrm{pH}$, type of solution, particle size, bubbling and temperature. Although $\mathrm{pH}$ is the most effective parameter for reducing $\mathrm{Cl}$ content in ash, using acid to lower $\mathrm{pH}$ is not an environmental friendly treatment considering wastewater treatment. It was found that $\mathrm{CO}_{2}$ bubbling in the form of microbubble is a proper treatment to decompose insoluble chloride as an environmental friendly treatment.
\end{abstract}

Key Words : Bottom ash, Chloride, Recycling, Microbubble

\section{Introduction}

Bottom ash can be used as raw materials of aggregates and cement products, because these components are very similar to those of them. One pretreatment method for recycling is to put bottom ash into melting process in order to reduce volume and stabilize heavy metals. However, fusion furnaces are not prevalent due to both environmental and economical drawbacks, i.e. large $\mathrm{CO}_{2}$ emission and high-energy cost. In addition, bottom ash contains halogen and heavy metals as impurities that have a negative influence on aggregates and cement. For example, there is a limit on chloride $(\mathrm{Cl})$ content in cement, i.e. less than 350 ppm in Japan, and less than $1000 \mathrm{ppm}$ in Europe. As $\mathrm{Cl}$ in aggregate and cement causes erosion especially for reinforced concrete, it is necessary to reduce the $\mathrm{Cl}$ content before recycling [1].

This paper discusses the removal of chloride from bottom ash not only from municipal solid waste incinerators (MSWI), but also from industrial waste incinerators. Previously there were some researches on removal of chloride from MSWI bottom ash $[2,3]$. Water extraction, i.e. washing method is generally known to be the most economic and simple method. However, it is difficult to lower the $\mathrm{Cl}$ content to less than $0.5 \%$ because of insoluble chloride, while normally the $\mathrm{Cl}$ content of bottom ash is about 0.5 $5 \%$. In order to decompose insoluble chloride, influence of the parameter, such as particle size, $\mathrm{pH}$ and bubbling method were investigated.

\section{Experimental}

\subsection{Sample}

Samples of bottom ash were taken from four incinerators in Japan. Two samples, named as "Ash A" and "Ash B", were from MSWIs, while other samples, named as "Ash C" and "Ash D", were from industrial waste incinerators. Size classification of the samples was performed after drying at $70^{\circ} \mathrm{C}$ for 2 days because ash includes about $20 \mathrm{wt} \%$ moisture. After ash was pulverized to coarse powder and then sieving was performed. There are many parameters that influence the washing efficiency, e.g. temperature, agitation method, pulp density (liquid/solid ratio), contact time, the number of washing steps, type of solution, $\mathrm{pH}$ (acid concentration), particle size and bubbling method. This study is focused especially on particle size, $\mathrm{pH}$ and bubbling method.

\subsection{Method of normal washing test}

Without bubbling, pulverized bottom ash and the solution were mixed at the pulp density of $10-100 \mathrm{~g} / \mathrm{L}$. Washing solutions used in this study were (1) de-ionized water, (2) hydrochloric acid, (3) nitric acid, and (4) sulfuric acid. $\mathrm{pH}$ of the solution was controlled by changing the concentration of each acid. Then, the slurry was agitated in a plastic bottle by using a shaker at the rotation speed of $200 \mathrm{stroke} / \mathrm{min}$. for 10 minutes. Then, the slurry was filtrated by using $5 \mathrm{C}$ filter paper and de-ionized water was poured in order to wash out the dissolved salts that remained on the surface of ash. After filtration, the residue was analyzed to determine the content of the remaining chloride, using ionchromatograph (DIONEX DX-100, column: AS10) after alkali 
fusion.

\subsection{Method of bubbling test}

In case of bubbling, the slurry was agitated for 10 minutes by using an impeller, together with bubbling. Air and $\mathrm{CO}_{2}$ were tested as bubbling gas. Figure 1 shows schematic diagram of bubbling test. In case of normal bubble shown in Figure 1 (a), bubbling was performed through glass filter. In case of microbubble shown in Figure 1(b), bubbling was performed by circulating water by a pump at the flow rate of $4 \mathrm{~L} / \mathrm{min}$. The water contains gas under pressure. Gas was supplied into the pressurized tank by a pump from outside air and dissolved into water at $0.3 \mathrm{MPa}$. In case of $\mathrm{CO}_{2}$ bubbling, plastic bag containing $\mathrm{CO}_{2}$ was connected to the pump in order to supply $\mathrm{CO}_{2}$.

When water is discharged from the pressurized tank, microbubbles are generated by rapid pressure reduction. Bubble's diameter is dependent on the flow speed and the speed of pressure reduction. In this experimental device, diameter of microbubble measured by image processing was minimum $4 \mu \mathrm{m}$, average 10 $40 \mu \mathrm{m}$, while that of normal bubble was a few millimeters. The flow speed of gas was kept constant at $0.2 \mathrm{~L} / \mathrm{min}$. Thus, total consumption of gas was $2 \mathrm{~L}$. The following procedure after bubbling is the same as method of the normal washing test.

\section{Results and Discussion}

\subsection{Properties of bottom ash}

Table 1 shows chemical composition of bottom ash by X-ray fluorescence spectrometer (XRF). Main components were $\mathrm{CaO}$, $\mathrm{SiO}_{2}, \mathrm{Al}_{2} \mathrm{O}_{3}$ and $\mathrm{Fe}_{2} \mathrm{O}_{3}$ in all four ashes. Figure 2 shows $\mathrm{X}$-ray diffraction (XRD) patterns of bottom ashes. In Ash A and Ash $\mathrm{B}$ from MSWIs, calcite $\left(\mathrm{CaCO}_{3}\right)$, gehlenite $\left(2 \mathrm{CaO} \cdot \mathrm{Al}_{2} \mathrm{O}_{3} \cdot \mathrm{SiO}_{2}\right)$ and Friedel's salt $\left(3 \mathrm{CaO} \cdot \mathrm{Al}_{2} \mathrm{O}_{3} \cdot \mathrm{CaCl}_{2} \cdot 10 \mathrm{H}_{2} \mathrm{O}\right)$ were identified as major crystalline phases. This XRD result corresponds to previously reported data $[4]$. On the other hand, XRD patterns of Ash $\mathrm{C}$ and Ash D from industrial waste incinerators were completely different. Ash $\mathrm{C}$ was amorphous with no specific peak. One of the reasons why Ash $\mathrm{C}$ was amorphous is that there exist many glassy materials in the surface of Ash $C$, because ash was partially molten due to high temperature of incineration. In Ash D, $\mathrm{NaCl}, \mathrm{CaTiO}_{3}$ and $\mathrm{ZnFe}_{2} \mathrm{O}_{4}$ were identified due to high content of $\mathrm{Cl}$, Ti and Zn. Moreover, there was no peak of Friedel's salt (FS) in Ash C and Ash D. In case of Ash D, S content is higher and Al content is lower than those of other ashes, i.e. the molar ratio of $\mathrm{S}$ to $\mathrm{Al}(\mathrm{S} / \mathrm{Al})$ is extremely high. By the reaction with sulfate ion, FS is changed into ettringite $\left(3 \mathrm{CaO} \cdot \mathrm{Al}_{2} \mathrm{O}_{3} \cdot 3 \mathrm{CaSO}_{4} \cdot 32 \mathrm{H}_{2} \mathrm{O}\right)$ (a)

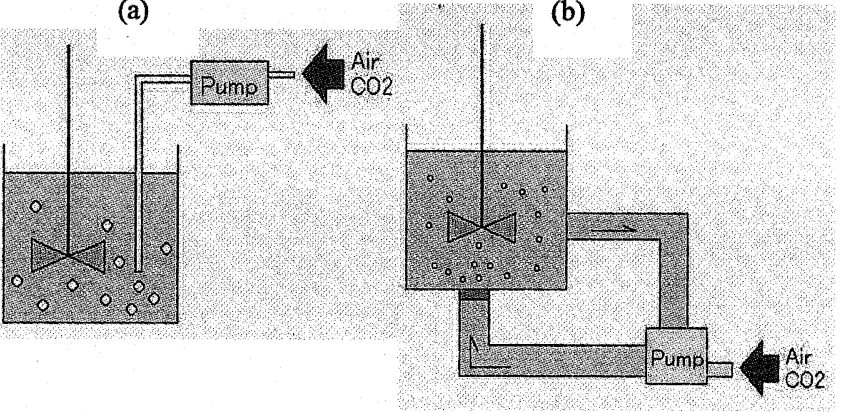

Figure 1 Schematic diagram of bubbling test. (a) Normal bubble, (b) Microbubble
Table 1 Chemical composition of bottom ash by XRF (unit: wt \%, ND: non detectable)

\begin{tabular}{c|c|c|c|c}
\hline & Ash A & Ash B & Ash C & Ash D \\
\hline $\mathrm{Ab}_{2} \mathrm{O}_{3}$ & 15.1 & 9.5 & 9.8 & 5.9 \\
\hline $\mathrm{SiO}_{2}$ & 35.5 & 21.9 & 39.8 & 22.4 \\
\hline $\mathrm{P}_{2} \mathrm{O}_{5}$ & $\mathrm{ND}$ & 0.9 & ND & 1.6 \\
\hline $\mathrm{SO}_{3}$ & 1.8 & 5.1 & 5.4 & 7.5 \\
\hline $\mathrm{Cl}$ & 1.2 & 1.5 & 1.0 & 9.7 \\
\hline $\mathrm{K}_{2} \mathrm{O}$ & 1.4 & 0.6 & 2.2 & 1.4 \\
\hline $\mathrm{CaO}$ & 33.8 & 51.4 & 14.2 & 16.7 \\
\hline $\mathrm{TiO}_{2}$ & 2.0 & 3.4 & 4.3 & 9.0 \\
\hline $\mathrm{Cr}_{2} \mathrm{O}_{3}$ & 0.1 & 0.04 & 0.1 & 0.2 \\
\hline $\mathrm{Fe}_{2} \mathrm{O}_{3}$ & 7.9 & 5.0 & 20.7 & 13.3 \\
\hline $\mathrm{CuO}$ & 0.4 & 0.2 & 1.2 & 8.4 \\
\hline $\mathrm{ZnO}$ & 0.9 & 0.4 & 0.8 & 3.9 \\
\hline
\end{tabular}

or monosulfate $\left(3 \mathrm{CaO} \cdot \mathrm{Al}_{2} \mathrm{O}_{3} \cdot \mathrm{CaSO}_{4} \cdot 12 \mathrm{H}_{2} \mathrm{O}\right)[5]$. In addition, dissolved chlorine ion once again fails to form FS due to the lack of $\mathrm{Al}_{2} \mathrm{O}_{3}$. From these reasons, it is inferred that FS was not confirmed in Ash D. It is suggested that FS formation occurs only when $\mathrm{S} / \mathrm{Al}$ is low and both $\mathrm{Ca} / \mathrm{Al}$ and $\mathrm{Al} / \mathrm{Cl}$ are sufficiently high.

Generally, FS is hardly soluble to cold water, while it is soluble to hot water and acid. When FS exists in bottom ashes, it is necessary to decompose FS in order to reduce the $\mathrm{Cl}$ content to less than $0.5 \%$.

\subsection{Experimental Results}

\subsubsection{Effect of particle size}

Figure 3 shows particle size distribution of four bottom ashes. Mean diameter of ash is $0.4 \mathrm{~mm}$ for Ash A and about $1 \mathrm{~mm}$ for other three ashes. Figure 4(a) shows the $\mathrm{Cl}$ content before

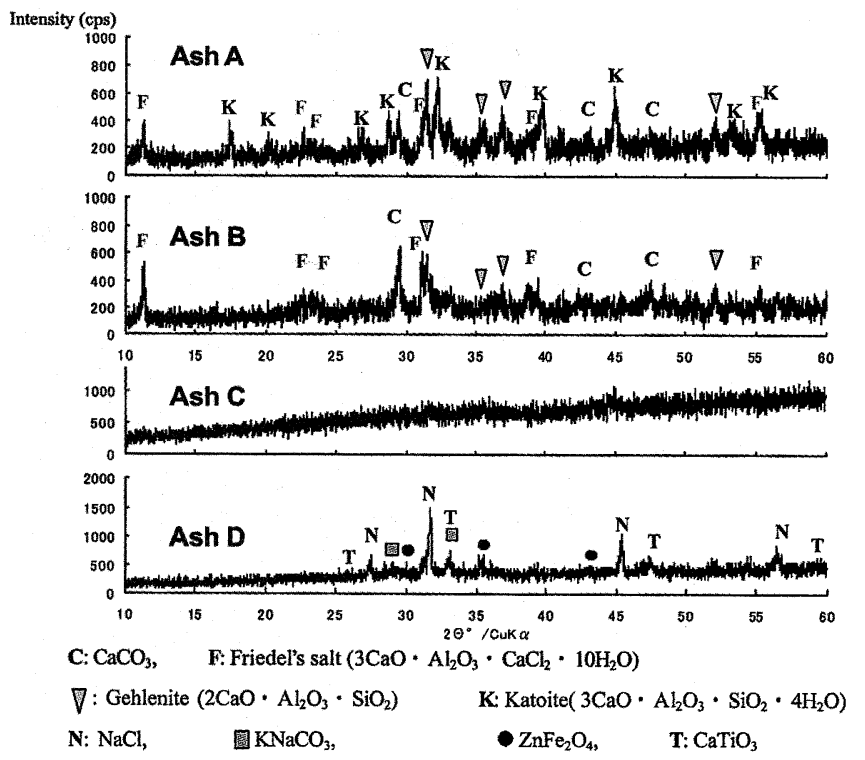

Figure 2 XRD patterns of bottom ashes 
washing at various size fractions, which were classified by sieving before grinding. In the same way, Figure 4(b) shows the removal rate of $\mathrm{Cl}$ after washing for 10 minutes. The $\mathrm{Cl}$ content in ash tends to be higher in smaller particles as shown in Figure 4(a), because smaller particles which have higher specific surface area take in more evaporated chlorine in the incinerated gas and also take in more chlorine ion in the quench water outside the incinerator. Furthermore, as shown in Figure 4(b), when particle size gets smaller, the removal rate of $\mathrm{Cl}$ increases. This result suggests that smaller particles contact with water more efficiently due to higher specific surface area. Therefore, grinding before washing is very effective.

\subsubsection{Effect of solutions and $\mathrm{pH}$}

Table 2 and Figure 5 show the result of washing tests using different solutions. Acid concentrations used in this experiment were $0.1 \mathrm{~N}$ and $2 \mathrm{~N}$. In water washing, the removal rate of $\mathrm{Cl}$ was very low, only $14 \%$. On the other hand, in acid washing, the removal rate was more than $40 \%$. Although nitric acid was most effective, it is not desirable to use nitric acid because there is an environmental standard for nitrogen content in wastewater. In case of hydrochloric acid $(\mathrm{HCl}), \mathrm{Cl}$ content after washing by $2 \mathrm{~N} \mathrm{HCl}$ was higher than that after washing by $0.1 \mathrm{~N} \mathrm{HCl}$. This means that $\mathrm{Cl}$ derived from $\mathrm{HCl}$ remained in the residue and $\mathrm{HCl}$ is not a proper solution. Considering practical use, sulfuric acid is the most suitable solution.

Figure 6 shows XRD patterns after washing using different solution. In case of washing by water, the peak of FS remained and

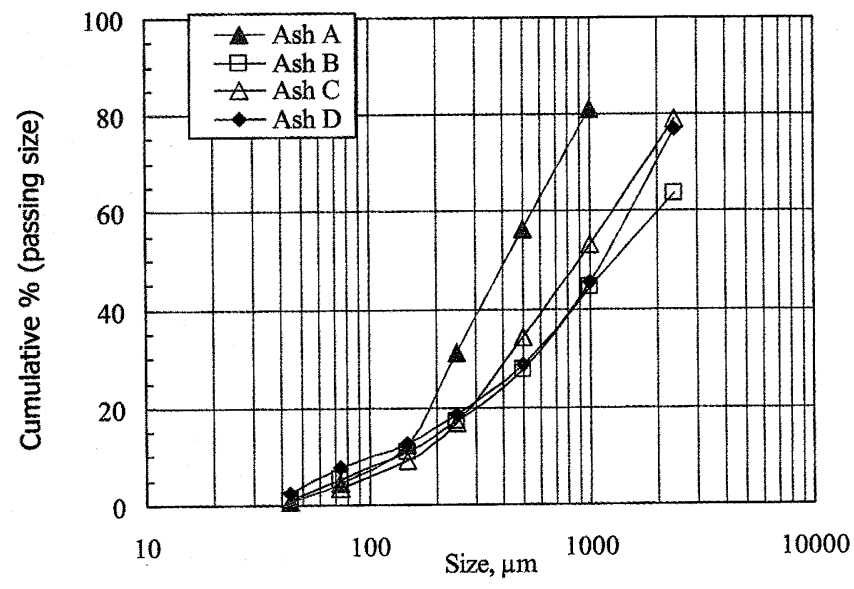

Figure 3 Particle size distribution of bottom ashes
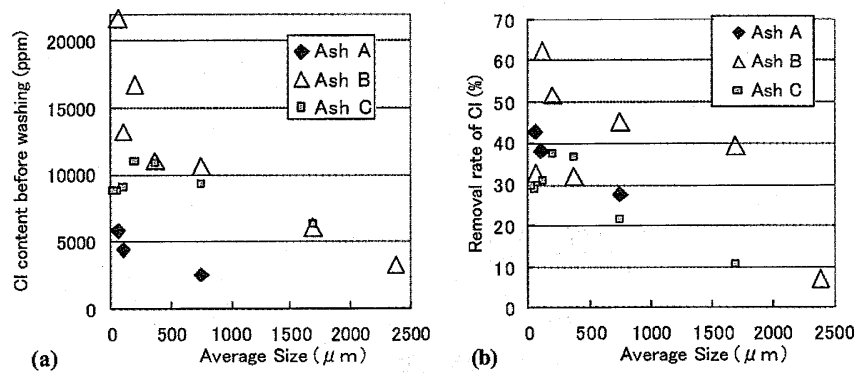

Figure 4 (a) $\mathrm{Cl}$ content before washing and (b) removal rate of $\mathrm{Cl}$ after washing at various size fractions (Liquid/Solid ratio: 10)
Table 2 Table 2. The results of washing tests for different solutions, Sample: Ash $\mathrm{A}(\mathrm{Cl}=7440 \mathrm{ppm})$, Liquid/Solid ratio: 10

\begin{tabular}{c|c|c|c|c|c}
\hline Solution & $\begin{array}{c}\text { Concentration } \\
\text { of Solution }\end{array}$ & $\mathrm{pH}$ of filtrate & $\begin{array}{c}\mathrm{Cl} \text { content of } \\
\text { residue } \\
\text { (ppm) }\end{array}$ & $\begin{array}{c}\text { Residue } \\
\text { weight } \\
\text { (g/g-ash) }\end{array}$ & $\begin{array}{c}\text { Removal } \\
\text { rate of } \mathrm{Cl}\end{array}$ \\
\hline $\mathrm{Water}$ & & 11.7 & 6400 & 0.96 & $17 \%$ \\
\hline $\mathrm{HCl}$ & $0.1 \mathrm{~N}$ & 9.5 & 4400 & 0.93 & $45 \%$ \\
\hline $\mathrm{HCl}$ & $2.0 \mathrm{~N}$ & 0.4 & 5640 & 0.50 & $62 \%$ \\
\hline $\mathrm{HNO}_{3}$ & $0.1 \mathrm{~N}$ & 8.3 & 4460 & 0.95 & $43 \%$ \\
\hline $\mathrm{HNO}_{3}$ & $2.0 \mathrm{~N}$ & 0.6 & 2540 & 0.44 & $85 \%$ \\
\hline $\mathrm{H}_{2} \mathrm{SO}_{4}$ & $0.1 \mathrm{~N}$ & 9.8 & 3670 & 0.94 & $53 \%$ \\
\hline $\mathrm{H}_{2} \mathrm{SO}_{4}$ & $2.0 \mathrm{~N}$ & 1.0 & 1880 & 0.98 & $75 \%$ \\
\hline
\end{tabular}

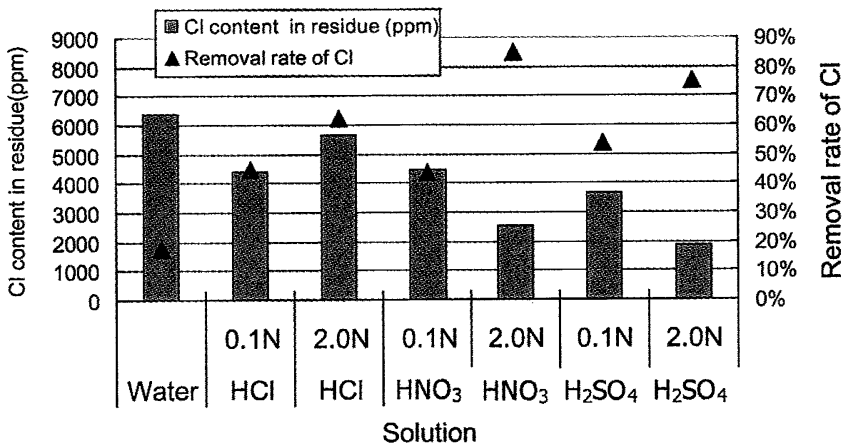

Figure $5 \mathrm{Cl}$ content and removal rate of $\mathrm{Cl}$ after washing by different solutions.

Sample: Ash A(Cl=7440 ppm), Liquid/Solid ratio: 10

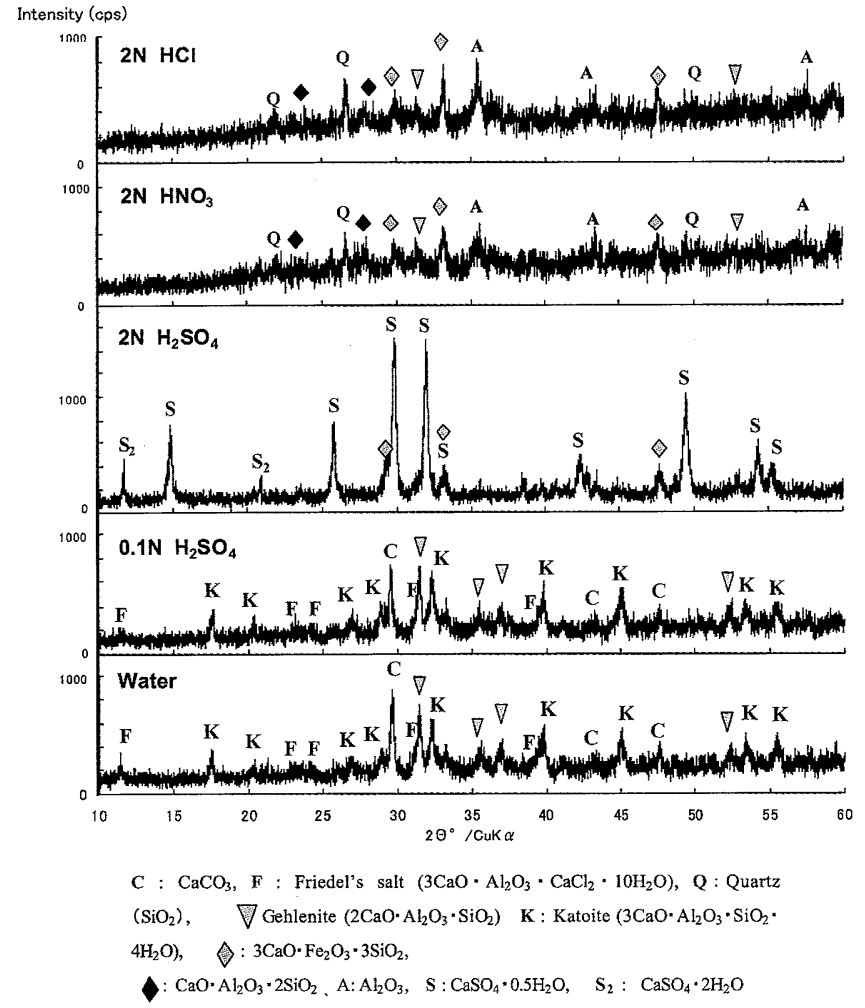

Figure 6 XRD patterns after washing by different solutions (Sample: Ash A) 
Table 3 The amount of eluted heavy metals $(\mathrm{Cu}, \mathrm{Pb}$ and $\mathrm{Zn})$ after washing by $\mathrm{H}_{2} \mathrm{SO}_{4}$

\begin{tabular}{c|c|c|c|c|c|c|c|c}
\hline & \multirow{2}{*}{$\begin{array}{c}\mathrm{pH} \text { of } \\
\text { filtrate }\end{array}$} & $\begin{array}{c}\text { Residue } \\
\text { weight } \\
\text { (g/g-ash) }\end{array}$ & $\mathrm{Cu}$ & $\mathrm{3}$ & $\mathrm{C}$ Content in solid (ppm) & \multicolumn{3}{|c}{ Eluted ratio (\%) } \\
\hline $\begin{array}{c}\text { Ash A before } \\
\text { washing }\end{array}$ & & & 1530 & 368 & 3920 & $\mathrm{Cu}$ & $\mathrm{Pb}$ & $\mathrm{Zn}$ \\
\hline $\begin{array}{c}\text { After washing by } \\
0.1 \mathrm{~N} \mathrm{H}_{2} \mathrm{SO}_{4}\end{array}$ & 9.8 & 0.94 & 1480 & 433 & 3610 & 9.0 & 0 & 13.4 \\
\hline $\begin{array}{c}\text { After washing by } \\
2 \mathrm{~N} \mathrm{H}_{2} \mathrm{SO}_{4}\end{array}$ & 1.0 & 0.98 & 731 & 345 & 1720 & 53.2 & 8.2 & 57.0 \\
\hline
\end{tabular}

total pattern is the similar to that before washing. On the contrary, in case of washing by $2 \mathrm{~N}$ acid, the peak of FS salt completely disappeared. In case of both nitric and hydrochloric acid, quartz and alumina were identified instead of calcium carbonate, while calcium sulfate $\left(\mathrm{CaSO}_{4} \cdot 0.5 \mathrm{H}_{2} \mathrm{O}\right.$ and $\left.\mathrm{CaSO}_{4} \cdot 2 \mathrm{H}_{2} \mathrm{O}\right)$ was identified in case of sulfuric acid. As shown in Table 2, residue weight after washing by $2 \mathrm{~N}$ sulfuric acid at $\mathrm{pH} 1$ was $0.98 \mathrm{~g} / \mathrm{g}$-ash,

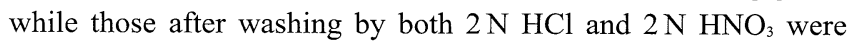
c.a. $0.5 \mathrm{~g} / \mathrm{g}$-ash. This result means that the ratio decreased by soluble component at $\mathrm{pH} 1$ is c.a. $50 \%$ and the ratio increased by formed calcium sulfate is c.a. $50 \%$. Therefore, the residue weight was kept at almost $1 \mathrm{~g} / \mathrm{g}$-ash.

Figure 7 shows the $\mathrm{Cl}$ content after washing as a function of $\mathrm{pH}$. $\mathrm{pH}$ has a clearly positive correlation with the $\mathrm{Cl}$ content and $\mathrm{pH}$ is more effective on $\mathrm{Cl}$ removal than any other parameters. However, the problem is that low $\mathrm{pH}$ causes ash leaching and also leaching heavy metals. Table 3 shows the amount of eluted heavy metals $(\mathrm{Cu}, \mathrm{Pb}$ and $\mathrm{Zn})$ after washing by $\mathrm{H}_{2} \mathrm{SO}_{4}$. As $\mathrm{pH}$ decreased, elution of heavy metals increased clearly. Therefore, when $\mathrm{pH}$ gets lower, the treatment of filtrate gets more difficult and costly.

\subsubsection{Effect of bubbling}

Table 4 and Figure 8 show the result of bubbling tests under different conditions (gas, ash and bubble size). In case of Ash A, the removal rate increased from $45 \%$ to $74 \%$ by using $\mathrm{CO}_{2}$ microbubbles. $\mathrm{CO}_{2}$ is more effective than air, and as for bubble size, finer bubble is more effective. As for Ash $\mathrm{B}$, the removal rate
Table $4 \mathrm{Cl}$ content and removal rate of $\mathrm{Cl}$ after bubbling test for different conditions

\begin{tabular}{c|c|c|c|c|c|c}
\hline $\begin{array}{c}\text { Washing } \\
\text { method }\end{array}$ & Ash & Gas & $\begin{array}{c}\mathrm{pH} \text { of } \\
\text { filtrate }\end{array}$ & $\begin{array}{c}\mathrm{Cl} \text { content } \\
\text { of ash } \\
(\mathrm{ppm})\end{array}$ & $\begin{array}{c}\mathrm{Cl} \text { content } \\
\text { of residue } \\
(\mathrm{ppm})\end{array}$ & $\begin{array}{c}\text { Residue } \\
\text { weight } \\
\text { (g/g-ash) }\end{array}$ \\
\hline Agitation only & Ash A & - & 11.7 & 10700 & 6180 & 0.93 \\
\hline Normal Bubble & Ash A & $\mathrm{CO}_{2}$ & 8.8 & 10700 & 4600 & 0.91 \\
\hline Micro Bubble & Ash A & Air & 11.3 & 9500 & 3930 & $*$ \\
\hline Micro Bubble & Ash A & $\mathrm{CO}_{2}$ & 7.1 & 10700 & 2910 & $*$ \\
\hline Micro Bubble & Ash B & $\mathrm{CO}_{2}$ & 7.2 & 25500 & 2120 & $*$ \\
\hline
\end{tabular}

Table 5 Comparing microbubbles and normal bubbles

\begin{tabular}{c|c|c}
\hline Parameter & Microbubble & Normal bubble \\
\hline Diameter $(\mathrm{mm})$ & $0.01-0.04$ & $1-10$ \\
\hline $\begin{array}{c}\text { Specific surface } \\
\text { area }\left(\mathrm{mm}^{2} / \mathrm{mm}^{3}\right)\end{array}$ & $150-600$ & $0.6-6$ \\
\hline $\begin{array}{c}\text { Rising speed } \\
(\mathrm{mm} / \mathrm{s})\end{array}$ & $0.1-1$ & $100-1000$ \\
\hline
\end{tabular}

is $92 \%$ after $\mathrm{CO}_{2}$ microbubbling. When compared with Ash $\mathrm{A}, \mathrm{Cl}$ removal from Ash B is more efficient. It is likely that Ash B has higher content of soluble chloride than Ash A. Table 5 compares various parameters between microbubbles and normal bubbles. Due to higher specific surface of microbubbles, it is much easier for particles to contact with $\mathrm{CO}_{2}$. Moreover, in case of microbubbles, rising speed is much slower and dissolution speed of $\mathrm{CO}_{2}$ gets higher. Thus, microbubbles are more effective in shorter reaction time.

Figure 9 shows XRD patterns of ash after bubbling. As shown in this figure, there is no peak of FS after $\mathrm{CO}_{2}$ bubbling, while the peak remains after air bubbling. The dissolution reaction of FS by $\mathrm{CO}_{2}$ is shown in Eq. (1).

$$
\begin{aligned}
& 3 \mathrm{CaO} \cdot \mathrm{Al}_{2} \mathrm{O}_{3} \cdot \mathrm{CaCl}_{2} \cdot 10 \mathrm{H}_{2} \mathrm{O}+3 \mathrm{CO}_{2} \\
& \quad \rightarrow 3 \mathrm{CaCO}_{3}+2 \mathrm{Al}(\mathrm{OH})_{3}+\mathrm{CaCl}_{2}+7 \mathrm{H}_{2} \mathrm{O}
\end{aligned}
$$

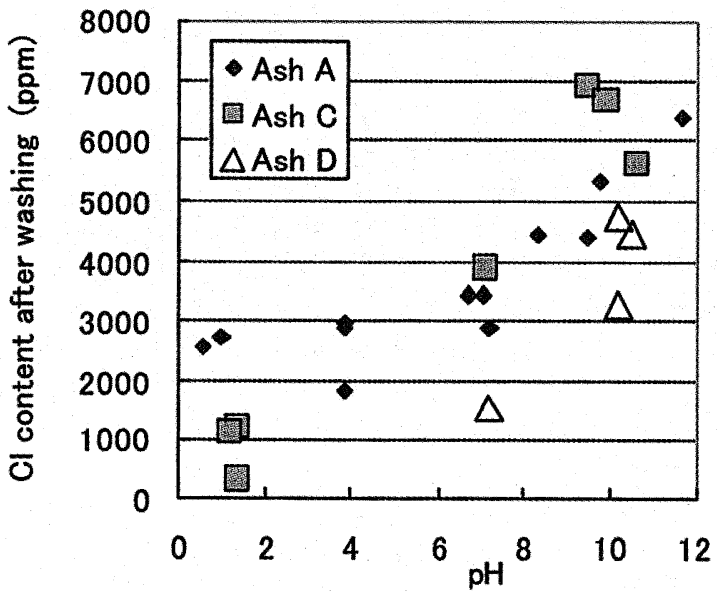

Figure 7 The relationship between $\mathrm{Cl}$ content after washing and $\mathrm{pH}$. Sample: Ash $\mathrm{A}(\mathrm{Cl}=7,440-10,700 \mathrm{ppm})$, Ash $\mathrm{C}(\mathrm{Cl}=8,830$ ppm $)$, Ash $\mathrm{D}(\mathrm{Cl}=70,800 \mathrm{ppm})$

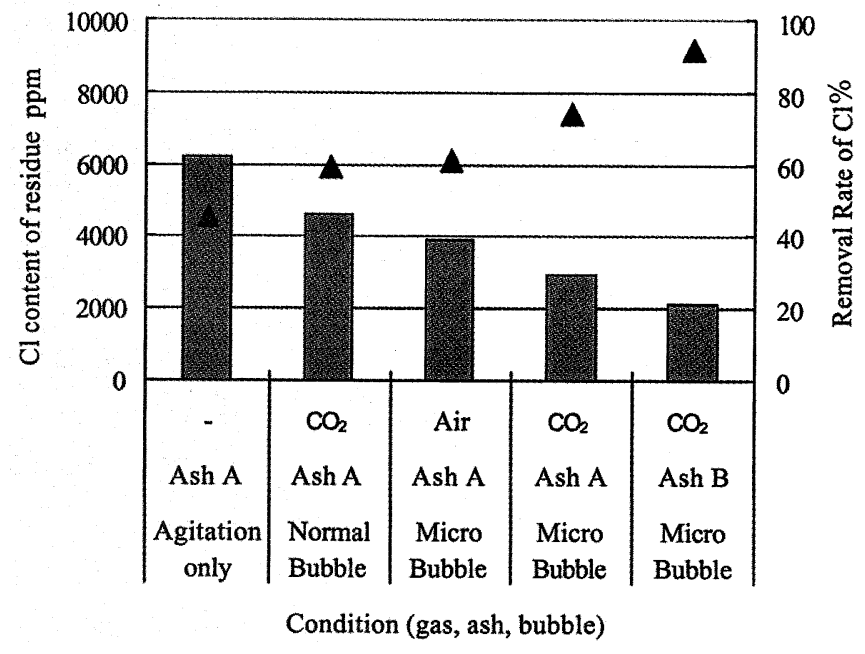

Figure $8 \mathrm{Cl}$ content and removal rate of $\mathrm{Cl}$ after bubbling test for different conditions 
Table 6 Bubbling test results adding the effect of acid and temperature $\left(\mathrm{CO}_{2}\right.$ microbubble: $0.2 \mathrm{~L} / \mathrm{min}$.)

\begin{tabular}{c|c|c|c|c}
\hline Solution & Temperature & pH of filtrate & $\begin{array}{l}\mathrm{Cl} \text { content after } \\
\text { bubbling (ppm) }\end{array}$ & $\begin{array}{l}\text { Removal } \\
\text { Rate of } \mathrm{Cl} \\
(\%)\end{array}$ \\
\hline $\mathrm{H}_{2} \mathrm{O}$ & $20^{\circ} \mathrm{C}$ & 7.1 & 3410 & 70 \\
\hline $0.1 \mathrm{~N}$ & & & & \\
$\mathrm{H}_{2} \mathrm{SO}_{4}$ & $20^{\circ} \mathrm{C}$ & 3.9 & 2860 & 75 \\
\hline $0.1 \mathrm{~N}$ & & & & \\
$\mathrm{H}_{2} \mathrm{SO}_{4}$ & $90^{\circ} \mathrm{C}$ & 3.9 & 1830 & 84 \\
\hline
\end{tabular}

Since $\mathrm{CaCO}_{3}$ formed by this reaction, the intensity of $\mathrm{CaCO}_{3}$ peak increased after $\mathrm{CO}_{2}$ bubbling as shown in Figure 9.

In Eq. (1), the residue after FS dissolution is assumed to be $\mathrm{CaCO}_{3}$ and $\mathrm{Al}(\mathrm{OH})_{3}$, because the solubility of these two is very small. Then, the ratio of residue weight is calculated to be c.a. $81 \%$ from molecular weight. When the weight percentage of FS in ash is $4 \%$ (i.e. $\mathrm{Cl}$ as $\mathrm{FS}=0.5 \%$ ), the decrease of ash weight by FS dissolution is calculated to be $0.8 \%$. This means that the change in weight by FS dissolution is very small.

Next, the effects of weak acid washing and temperature on $\mathrm{Cl}$ removal were investigated, together with $\mathrm{CO}_{2}$ microbubbles. Table 6 shows the results. By using $0.1 \mathrm{~N}$ sulfuric acid, the removal rate of $\mathrm{Cl}$ slightly increased from $70 \%$ to $75 \%$. Besides, by raising the

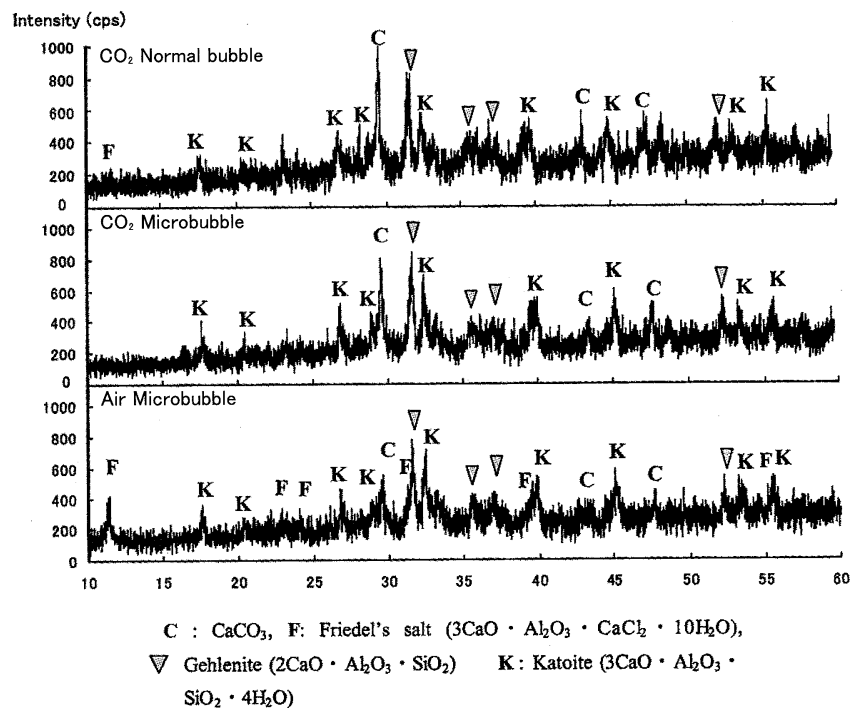

Figure 9 XRD patterns of ash after bubbling test temperature up to $90^{\circ} \mathrm{C}$, the removal rate increased up to $84 \%$. These results suggest that not only $\mathrm{CO}_{2}$ in flue gas but also waste heat are available for efficient washing.

\section{Concluding Remarks}

In order to recycle bottom ashes as raw materials of cement, removal of $\mathrm{Cl}$ from ashes was investigated. Friedel's salt was identified as the main chloride by XRD analysis. Both washing by strong acid and $\mathrm{CO}_{2}$ bubbling were very effective to decompose Friedel's salt. However, $\mathrm{CO}_{2}$ bubbling is better because strong acid washing is not environmental friendly due to dissolution of heavy metals from ash.

The grinding process is very important to achieve a high efficient removal of $\mathrm{Cl}$, because high specific surface is needed. When bubbling by $\mathrm{CO}_{2}$ is performed, fine microbubbles are more effective than normal bubbles as they attach more easily to particles. In addition, removal rate of $\mathrm{Cl}$ increases by using diluted sulfuric acid at a high temperature in addition to $\mathrm{CO}_{2}$ microbubbling,

\section{Acknowledgments}

The present work was supported in part through the $21 \mathrm{st}$ Century COE Program, "Mechanical Systems Innovation," by the Ministry of Education, Culture, Sports, Science and Technology, Japan. Moreover, the work was also supported by cooperation research with the Industrial Waste Recycling R\&D Center, Korea Institute of Geoscience and Mineral Resources.

\section{Reference}

[1] Takahashi, H., Maruta, T., Sakae, K. and Kasahara, M., "Application of water-washed incineration fly ashes as cement raw material," (in Japanese), Inorg. Mater., Vol.5, pp.200-207, (1998)

[2] Abbas, Z., Moghaddam, A.T. and Steenari B., "Release of salts from municipal solid waste combustion residues," Waste Manage., Vol.23, pp.291-305, (2003).

[3] Li, M., Xiang, J., Hu, S., Sun, S., Li, P. and Sun, X., "Characterization of solid residues from municipal solid waste incinerator," Fuel, Vol.83, pp.1397-1405, (2004).

[4] Bethanis, S., Cheeseman, C.R., and Sollars, C.J., "Properties and microstructure of sintered incinerator bottom ash," Ceramics Int., Vol.28, pp. 881-886, (2002)

[5] Ohmori, H., Maruta, T., Moriya, M. and Isoda, H., "Decreasing the amount of chloride ion elution in the ecocement made from municipal waste ash," (in Japanese), Inorg. Mater., Vol.4, pp.119-125, (1997). 